\title{
Brexit: An unhappy marriage to the single market
}

\author{
Warren Matthews \\ Belhaven University, Houston, USA \\ Robert Driver \\ LeTourneau University, Houston, USA
}

\section{Key Words}

Common market, European Union, single market

\begin{abstract}
The United Kingdom has voted to exit the European Union. Within the European Union, the rich states of the north (led by Germany) control most policies, and the less rich states of the southern tier are suffering the effects of austerity (Greece, Spain, Italy). Traditional political parties are losing strength, and populist and nationalist parties are gaining votes and forming coalition governments (Greece, Spain, Italy). The European Union is not serving the needs of all its members, and this casts doubt on the concept of a union of sovereign nations.
\end{abstract}

Corresponding author: Warren Matthews

Email address for corresponding author: wmatthews@belhaven.edu

First submission received: $7^{\text {th }}$ February 2019

Revised submission received: $25^{\text {th }}$ March 2019

Accepted: $30^{\text {th }}$ March 2019

\section{Introduction}

On June 23, 2016, almost 34 million voters went to the polls in the United Kingdom. In a result that was surprising to many, they voted $52 \%-48 \%$ to leave the European Union (EU). Since then policy makers on both sides of the English Channel have struggled to figure out how - and how smoothly - a nation exits the EU. There appears to be a deadline of March 29, 2019 to implement the exit, but little progress has been made on working out the details. The British exit, or "Brexit", provides a case study in macroeconomic policy toward trade, as well as many related issues. The central problem is that in joining the EU, nations sacrificed part of their national sovereignty to achieve a single market. Now the general public is starting to resist and reassert their sovereign rights to control their borders and domestic law. (Drozdiak, pp 27-48).

The worst-case scenario is that in March of 2019 much merchandise trade out of the UK will come to a halt at the border as Customs officers struggle to evaluate paperwork documenting country of origin and product contents. Even the goods that easily pass inspection could be held up in long queues awaiting evaluation. Note that most of these border Customs officers do not yet exist because currently goods flow across the border without inspection. The case of the border between Northern Ireland and the Republic of Ireland is especially difficult. A strict border would be required by EU law, but an open border was promised in the settlement of the "troubles" in the 1990s and more recently by Prime Minister Theresa May. (Dunt, pp 9-17).

\section{Literature Review}

The fifty-year history of the European Union is well documented (Nordvig 2014, Rodrik 2011, Stiglitz 2018, Blyth 2015, Clarke 2017, and Dunt 2016). Growing tensions within the European Union since 
the financial crisis of 2009 are bringing populist reaction and replacement of governments (Bremmer 2018, Drozdiak 2017, Evans 2017, Krastev 2014 and Krastev 2017). Now the UK has voted to exit the EU, and unchartered waters lie ahead (Shipman 2016, Shipman 2017, Zielonka 2014, Zielonka 2018, and Krastev 2017).

\section{The European Union}

A former official of the European Parliament and Prime Minister of Belgium summed up the key problem with the common currency of the EU: “...it remains a puzzle how the people of Europe managed to set up a currency union and introduce the euro without first laying a firm political and economic foundation." (See Verhofstadt 2017, p 229.)

The European Union was formed in 1957 with the signing of the Treaty of Rome as the European Economic Community (EEC). The Treaty of Rome, signed by France, West Germany, Italy, Belgium, Luxembourg, and The Netherlands, was intended to end a century of European wars and trade disputes by promoting the free movement of goods, services, capital and people, "the four freedoms". The UK joined the EEC in 1973. The Common Agriculture Policy was developed in the 1960s. In 1987 the Single European Act created the common market, setting the stage for peaceful expansion of trade without tariffs or other barriers. This agreement also set the stage for the common currency - the Euro, which was initiated in electronic form in 1999. The overarching goal of the EU was to form an "ever closer union" of members that would promote peace, trade, and economic growth. (See Bootle).

There are currently 28 members of the European Union, and 17 of the members use the Euro (the Eurozone) as their common currency. The United Kingdom never adopted the Euro, but it is a full EU member, which involves being constrained by EU law, being subject to the European Court of Justice, and paying a substantial annual payment toward the EU budget. All EU members are obligated to accept the free flow of goods, services, capital, and people from any other member state. The European Commission, based in Brussels, maintains the regulatory apparatus to provide EU-wide competition (antitrust) policy, control of state aid to firms, environmental controls, food safety regulations, and the Common Agriculture Policy. The European Central Bank manages the Euro money supply and monetary policy, and efforts are underway to regulate and insure commercial banks (the Banking Union). The European Parliament, an elected body, exercises limited oversight of the European Commission. The European Council, consisting of the Prime Ministers/Presidents of the member nations, negotiates policy and initiates legislation to be considered by the European Parliament. The European Court of Justice resolves disputes with decisions that are binding on all EU member states. (See Hannan, 2016a, and Hannan, 2016b).

Over the past 25 years, the EU bureaucracy in Brussels has gained more powers, and citizens in many member states are frustrated that they are subject to numerous EU laws and regulations that they cannot change. The European Court of Justice has issued rulings unpopular in the several nations. These unpopular rulings have contributed to nationalist political victories in France (Marine Le Pen), Italy (Five Starr and the League), Greece (Syriza), Germany (AfD Party), Austria (Hofer) and in the UK (UKIP, Brexit). Much of the EU "constitution" is in the form of treaties that require unanimous agreement of 28 nations to change. (See Oliver, 2017, and Oliver, 2018). (See Armstrong).

Recent economic and geo-political events have strained relations throughout the EU. The "Great Recession" in the US (2007-2009) and the ensuing world financial crisis exacerbated fiscal difficulties in Greece and other southern EU nations. The European Central Bank, the International Monetary Fund, and the European Council imposed severe austerity policies on several southern periphery nations in exchange for aid, while these nations struggled with severe recession and unemployment rates above $30 \%$. 
In Greece, these severe austerity policies have been in place for several years with little indication of economic growth or improvement in the labor market. Young people are voting with the anti-EU parties, and the Syriza Party won the last general election. (Blyth, pp 51-96).

In Italy, almost $30 \%$ of young adults aged 20-34 are not working or in school. Most older workers work under long term contracts with strong job security, while $62 \%$ of work contracts for those under age 25 are short term, with no job protection. Many young people have left the country, and marriage rates and birth rates are falling. In the recent national elections, the traditional political parties failed to collect the majority of votes, and new, nationalist or populist parties dominated the vote. Now a coalition government has been formed by the Five Star Movement and The League. Before the election campaign these groups were calling for exiting the Euro and banning immigration.

In Spain, Prime Minister Rajoy was been replaced by a minority party coalition. Almost $40 \%$ of Spaniards under age 35 said they support the far-left Podemos Party.

Recent migrations of large numbers of refugees from Syria and from North Africa have added to the financial and cultural burdens faced by EU members. Germany committed to accept 1 million refugees, but other Eastern European EU members have refused to accept any. Recently Italy turned away a boat load of refugees from North Africa, which was subsequently accepted by Spain. Under EU law, refugees accepted in any member state can migrate freely to any other member state. Analysis of the recent UK election results shows that regions adversely affected by large numbers of migrants more likely voted for Brexit.

The general message of these developments throughout the EU is that economic growth is not shared by all segments of society, and young people are not supporting the same traditional political parties of their parents. Very high youth unemployment and failures of the social safety net may well lead to a rejection of the EU or a rejection of free market economies, especially in the southern tier states.

\section{The Referendum of June 2016}

Prime Minister David Cameron was under pressure from his Conservative Party Members of Parliament (MP) to lead an exit from the EU. Like most college-educated Britons, he favored staying in the EU with certain reforms and conditions. Data from the British Social Attitudes survey in 2015 showed that only $18 \%$ of the British people favored leaving the EU, while $37 \%$ favored remaining in the EU with certain reforms, and 26\% favored remaining without reforms. (Evans and Menon, p 47). But Cameron was under growing pressure to lead a reform or exit movement. Finally, in 2015 he agreed to call a referendum, but only after he negotiated a series of reforms with the EU to address the concerns of Brits.

As it turned out, Prime Minister Cameron did achieve many of the reforms he sought. The EU agreed to exempt the UK from the "ever closer union" concept (in future treaties). The EU agreed that non-Euro members of the EU would not help finance any bailouts of Euro states or any expense of supporting the Euro. The EU agreed that the UK could restrict certain welfare and non-resident child support payments to refugees. In addition, the UK could restrict the numbers of immigrants in case of "overriding reasons of public interest". (Drozdiak, pp 27-48). Cameron felt these reforms would address most concerns, and, true to his word, he called a referendum for June 23, 2016. Most professionals and young adults seemed to strongly favor remaining in the EU. Many working-class people, who were frustrated by immigration, globalization, EU regulations, and nationalist feelings - favored exiting the EU. Older voters tended to favor exiting the EU, and they had a high voter turnout rate. Most voters under 30 preferred the remain camp, but they had a lower voter turnout rate. Although virtually all polls predicted a "Remain" vote, the "Leave" campaign won the vote by a slim majority. The next day David Cameron resigned, and soon Theresa May was selected as Prime Minister. Although she, as most MPs, had favored 
the Remain camp, she vowed to follow the will of the people and lead the Brexit effort (Evans and Menon). She appointed some leaders of the "Leave" campaign to key posts in her government.

\section{Article 50}

The Lisbon Treaty of 2009 provided the only guidance for a member state to leave the EU. It was Article 50, a very short Article with few details. It requires a member state to implement Article 50 by providing notice of leaving to the European Council, and then exit within two years. It appears that much more time than two years would be necessary to negotiate the administrative, legal, and economic treaties needed. (The recent EU-Canada trade agreement took seven years to negotiate, and the recent EU-Japan trade agreement took five years to complete.)

The administrative exit involves settling financial obligations of the UK to the EU for commitments made prior to exit. It also must deal with the residency rights of UK citizens living in the EU and EU citizens living in the UK. The legal exit must deal with unraveling the last 50 years of intertwined UK and EU law. The trade exit involves (if the UK leaves the single market) a complete renegotiation of any and all trade terms with EU members. In addition, the EU has negotiated many trade deals with non-EU nations, and now the UK would no longer be covered. So, the UK must replace these deals with bilateral trade arrangements to protect these trading relations (Dunt, pp 28-36).

The author of Article 50, former Prime Minister Giuliano Amato of Italy, said "My intention was that it should be a classic safety valve that was there, but never used" (Dunt, $p$ 29). Prime Minister Theresa May implemented Article 50 on March 29, 2017, so March 2019 is a critical deadline. So far it seems that negotiations have moved very slowly, and the two-year period is more than half gone. (See Halligan and Lyons).

\section{The Single Market}

The single market has long been a goal for many political leaders in most EU nations. It involves the widespread acceptance of the "four freedoms" - the free movement of goods, services, capital, and people among all EU nations. The single market was agreed to in the Single European Act of 1987, and it was fully implemented in 2002 with the introduction of Euro notes and coins. The necessary feature of a single market is that borders become unregulated and all goods, services, capital and people from a member state can enter any other member state without Customs officer review. Licenses, product content, country of origin certificates and passports are accepted without question. Once the Euro notes and coins were introduced (now in 17 nations), trade across borders became very efficient and unrestricted.

Upon exiting the EU, the UK may or may not leave the single market. This outcome will be subject to negotiation. The EU policy is that without honoring the four freedoms, the UK cannot remain in the single market. The UK position is that the requirement to accept unlimited immigration without controls is unacceptable. Many in the UK would like to stay in the single market to preserve important export markets but are not willing to accept unlimited immigration. The outcome of this negotiation is unknown.

One way to preserve export markets outside the EU single market is to negotiate "mutual recognition agreements" with individual nations, both EU members and other nations around the world. Such agreements would involve each nation accepting the standards and paperwork of the other. It would take a long time to negotiate such agreements, and the terms might be different in each case. The UK probably does not have near enough qualified trade officials to undertake such a project, certainly by March 2019 (Dunt, pp 40-58). 


\section{European Economic Area (EEA)}

Norway, Iceland, and Lichtenstein, although not EU members, entered the EU single market through the formation of the European Economic Area (EEA). This may be a model the UK could use to maintain access to the single market, but it would require acceptance of the four freedoms, loss of any voice in EU governance, and continued but reduced payments toward the EU budget. (Wambach). The EEC does not include the European Supervisory Agencies on banking, insurance, and security markets. These sectors are essential to the City of London as a major world financial center. The EEA may provide a suitable solution for the UK, but only if the financial issues can be resolved in the UK's favor. However, the nations of France, Germany and Ireland must agree, and they are hoping to benefit if there is a massive exodus of financial firms from London seeking to continue to serve their clients in the rest of Europe (Dunt, pp 65-75).

\section{The Switzerland Model and the European Free Trade Association}

The Swiss have developed an arrangement with the EU since 1992 that seems to be what Prime Minister May is seeking. The Swiss have access to the single market through a complex series of bilateral agreements with EU members. Swiss law often requires a referendum on important issues, which is why they did not join the EU in 1992. Updating the agreements is done through EU-Swiss negotiations, but the EU dominates the discussion. The EU requires that the Swiss accept all agreements as a single package, and they do. Because this system is so cumbersome and at odds with the EU membership model, it seems unlikely it could be a model for the UK access to the single market (Dunt, pp 76-80). (Owen, 2012).

\section{A Customs Union - Turkey and Canada}

A customs union is a group of nations that do not charge tariffs to each other, and they adopt a standard tariff to imports from outside the customs union. It deals only with tariffs (taxes on imported goods), so it does not deal with the cross-border flow of services, capital, or people. This would eliminate the concern in the UK about immigration. However, members of a customs union are not free to negotiate trade agreements with nations outside the custom union. That runs counter to the plans of the UK to do just that as a way to replace European export markets.

Currently Turkey is the only nation that is in the European Customs Union and not a member of the EU. Turkey gained this status as a step toward EU membership, but that path seems to be off the table. It does not seem likely that there is a customs union path for the UK unless it can be negotiated along the lines of the EEA.

Leaving the customs union would subject British exporters to rules about documenting country of origin and correct product classification for customs purposes. This could become a bureaucratic nightmare that would clog ports and highways as Customs Officers and exporters struggle with the new rules.

Canada and the EU recently concluded a trade deal (CETA) after seven years of talks. One aspect of such a deal is that once concluded, it must be passed by every EU member national parliament. Political factors can block approval for reasons unrelated to trade. This is a challenge the UK would face in attempting to make trade deals on a wide range of goods with the EU, especially with the March 2019 deadline looming.

\section{The Findings}

Prime Minister Theresa May has been leading the Brexit preparations for two years. Her plans are closely held, and several of her Ministers have resigned in protest as her plans have unfolded. There are many opinions as to how the UK should proceed. The more militant "Leave" supporters favor a "hard Brexit" that would involve leaving the customs union and the single market. This solution would restore 
the ability of the UK to control its immigration policy at the border, but it would require the negotiation of numerous trade agreements, and probably involve border congestion for quite some time. (Dunt).

Those who favored the "Remain" camp tend to want a re-vote to cancel the Brexit. Many oppose this idea as an affront to democracy. Even PM May, who quietly supported the "Remain" camp, says "Brexit means Brexit" as she works to carry out the will of the voters.

A middle ground strategy might be to remain in the single market and customs union through the European Economic Area (EEA) mechanism. This "Norway" strategy involves leaving the EU but joining the EEA. The UK was a founding member of EEA and is technically still a member. This exit from the EU would keep the UK in the customs union, prevent outside trade agreements, and continue payments toward the EU budget. The "Norway" plan would facilitate continued trade relations, and it would subject the UK to the European Court of Justice, EU law, and EU immigration policy. These were some of the key issues driving the "Leave" voters in the 2016 referendum. (Drozdiak, pp 27-48).

Prime Minister Theresa May submitted her plan for Brexit to Parliament, and on January 15, 2019 that plan was rejected by a vote of 332-302. This defeat was the most severe ever suffered by a UK government. However, in the same week PM May survived a no confidence vote, and she is continuing to craft a plan that can pass muster in Parliament and the EU. It does not appear that EU officials are receptive to changing the terms of Brexit. On March 29, Parliament rejected a similar Withdrawal Bill for the third time. Without further compromise, the UK will exit the EU on April 12 with no plan. It appears that there would be a sudden requirement for border inspections and documentation of the point of origin for most goods. The UK and the EU are not prepared for these requirements.

\section{Summary and Conclusions}

The European Union represents a culmination of many years of negotiation and political maneuvering to achieve the "four freedoms" of the free movement of goods, services, people and capital. It was seen as a way to end hundreds of years of war and trade conflicts in Europe. The fatal flaw of the concept is that sovereign nations must agree to sacrifice some of their sovereign powers to create the EUwide institutions and policies that all must live by.

The UK voted in 2016 to exit the EU, and negotiations since then have been slow and incomplete. The deadline of 29 March was adjusted to 12 April or later. Some observers favor a "hard Brexit" to quickly get on with the structuring of new trade arrangements (See Halligan and Lyons). Others fear massive disruption to the flow of essential food and medicines, and the government has created stockpiles (See Dunt). Only time will tell how smoothly a nation can exit the EU, and its other EU member nations will follow.

\section{References}

Armstrong, K. (2017). Brexit Time: Leaving the EU - Why, How and When? Cambridge: Cambridge University Press. Blyth, M. (2015). Austerity - The History of a Dangerous Idea, Oxford: Oxford University Press.

Bootle, R. (2017). Making a Success of Brexit and Reforming the EU. London: Nicholas Brealey Publishing.

Bremmer, I. (2018). Us vs. Them - The Failure of Globalism, New York: Portfolio/Penguin.

Clarke, H., M. Goodwin, and P. Whiteley (2017). BREXIT - Why Britain Voted to Leave the European Union, Cambridge: Cambridge University Press.

Drozdiak, W. (2017). Fractured Continent - Europe's Crises and the Fate of the West, New York: W. W. Norton \& Company.

Dunt, I. (2016). BREXIT - What the Hell Happens Now? Surrey UK: Canbury Press.

Evans, G. and A. Menon (2017). BREXIT and British Politics, Cambridge UK: Polity Press.

Halligan, L and G. Lyons. (2018). Clean Brexit: Why Leaving the EU Still Makes Sense, London: Biteback Publishing.

Hannan, D. (2016a). Why Vote Leave, London: Head of Zeus, Ltd.

Hannan, D. (2016b). What Next: How to Get the Best from Brexit, London: Head of Zeus, Ltd. 
Krastev, I. (2014). Democracy Disrupted - The Politics of Global Protest, Philadelphia: University of Pennsylvania Press.

Krastev, I. (2017). After Europe, Philadelphia: University of Pennsylvania Press.

Nordvig, J. (2014). The Fall of the Euro - Reinventing the Eurozone and the Future of Global Investing, New York: McGraw-Hill Education.

Oliver, T. (2017). What Does Brexit Mean for the European Union? In D. Bailey and Leslie Budd, editors, The Political Economy of Brexit. Newcastle upon Tyne, UK: Agenda Publishing.

Oliver, T. (2018). Understanding Brexit - A Concise Introduction, Bristol: Policy Press.

Owen, D. (2012). Europe Restructured: The Eurozone Crisis and Its Aftermath, York: Methuen \& Co.

Rodrik, D. (2011). The Globalization Paradox, New York: W. W. Norton \& Company.

Shipman, T. (2016). All Out War - The Full Story of Brexit, London: William Collins.

Shipman, T. (2017). Fall Out - A Year of Political Mayhem, London: William Collins.

Stiglitz, J. (2018). Globalization and its Discontents, New York: W. W. Norton \& Co.

Wambach, A. (2018). The EU Single Market - 25 Years of Success with Room for Improvement, ZEW News, Mannheim Centre for European Economic Research - ZEW, May/June 2018.

Verhofstadt, G. (2017). Europe's Last Chance: Why the European States Must Form a More Perfect Union. New York: Basic Books.

Zielonka, J. (2014). Is the EU Doomed? Cambridge: Polity Press.

Zielonka, J. (2018). Counter Revolution - Liberal Europe in Retreat, Oxford: Oxford University Press. 